\title{
HAS MAN A GEOLOGICAL HISTORY IN AUSTRALIA
}

\author{
By R. Etheridge, Jun., \&c. \\ (Paleontologist to the Australian Museum, and Geological \\ Survey of N.S. WALES.)
}

(Plate XI, figs. 6-7).

The question has frequently presented itself-Are there any geological traces of man on this Continent, such as exist in other countries, and whereby the presence of a former race, or the antiquity of the present fast disappearing one, can be traced? The answer given by those most competent to judge is-No !

Let us examine the evidence on which this opinion is based The late Mr. R. Brough Smyth, in his excellent work, "The Aborigines of Victoria," says: "It is remarkable that no stone hatchet, chip of basalt, or stone knife has been found anywhere in Victoria except on the surface of the ground or a few inches beneath the surface. It is true that fragments of tomahawks and bone needles have been dug out of Mirrn-yong heaps on the sea-coast, covered wholly or partially by blown-sand ; but though some hundreds of square miles of alluvia have been turned over in mining for gold, not a trace of any work of human hands has been discovered. Some of the drifts are not more than three or four feet in thickness (from the surface to the bed-rock), and the fact that no Aboriginal implement, no bone belonging to man, has been met with, is startling and perplexing."**

Mr. Smyth adds: "Within quite recent periods . . . large rivers, like the Snowy River in Gippsland, have in some places changed their beds. . . . Such old beds and channels have been completely dug over by gold miners, and the detritus and 
débris have been washed; but, as far as I know, there has not been recorded any discovery of native implements. In much older gravels, clays, and sands underlying Recent $\mathrm{V}_{\text {olcanic rocks, }}$ where occur fossil fruits belonging to genera now found only in the northern parts of Australia, the miner has carried his explorations ; but nothing belonging to man has been seen. More recent deposits, in which are imbedded trunks of trees, and where the cones of the Banksia, leaves of several species of eucalypts, and remains of marsupials are of common occurrence, are likewise barren. The tracts where, over a large area, volcanic ash, some thirty or forty feet in thickness, overlies a grass-clad surface once trod by the native dog, and on which his bones are found, retain no trace of the native. Even the caves which have been explored exhibit no other than very recent evidences of the existence of man."**

Another writer, the Rev. P. MacPherson, M.A., of equal authority, arrives at much the same conclusion, for after fully discussing the question for and against, he concludes by saying: "Up to date, direct evidence for a geologic antiquity on behalf of the Australian aborigines seems to be very scanty." $\dagger$ The same author, in an excellent description of the "Oven-mounds of the Aborigines of Victoria," $\ddagger$ shows that even these large accumulations, with their varied contents, do not assist in a solution of the question, for their rate of increase and size is no more than can be accounted for in the historical period, as we used the term here.

The only hitherto recorded facts which can be brought in opposition to these views known to the writer are the following, and even they, from the uncertainty attached to the rate of increase of Post-Tertiary deposits, cannot be regarded as carrying much weight. Perhaps the best authenticated is the Bodalla

* Loc. cit.

+ "Stone Implements of the Aborigines of Australia, \&c." Journ. R. Soc. N. S. Wales for 1885 [1886], xix. p. 119.

$\ddagger$ Journ. R. Soc. N. S. Wales for 1884 [1885], xviii., p. 58. 
tomahawk, which is referred to by Mr. C. S. Wilkinson* in the following words :- "No human remains have yet been found with the bones of the extinct animals, but a stone hatchet has been obtained on the Bodalla estate, in the alluvium, at a depth of 14 feet from the surface."

The next case came under the personal observation of the Government Geologist and the writer. Mr. C. S. Wilkinson, when making a geological survey of the Cape Otway coast, in Victoria, in 1864, found in the sand dunes, two miles east of the Cape Otway light-house, flint chips, a sharpened stone tomahawk, and several bone "needles." The writer, a year or two later, obtained near the same locality a similar bone spike in a mixture of beach material, pebbles, and broken shells resting on the Mesozoic Carbonaceous Sandstone forming the high cliffs of the Cape, and apparently intermediate between that deposit and the overlying dunes, $\dagger$ " Remains of this nature, lying as they did beneath sand dunes at least two hundred feet high, must have been of great antiquity." $\ddagger$

The method employed by the aboriginals to sharpen their stone tomahawks is too well known to need description, but the following curious passage occurs in Bennett's " History of Australian Discovery and Civilisation: §-“ "In sinking wells and other excavations in the Hunter Valley, flat rocks with these axe-marks on their surfaces have been discovered at the depth of thirty feet or more below the present surface level, and covered with a drift or alluvium which in all probability must have taken thousands of years to accumulate."

Lastly, the late Mr. James Bonwick states that at Ballarat a basaltic "stone weapon, or tool-head, was unearthed during the

* " Notes on the Geology of New South Wales" (Dept. Mines, Sydney), 1887, p. 90 (4to, Sydney, 1887, Government Printer, 1la 64-87).

† Trans. R. Soc. Vict. 1876, xii. p. 3.

‡ Records Geol. Survey, N. S. Wales, 1889, I. pt. 1, p. 15.

§ P. 263 (8vo, Sydney, 1867). 
process of gold-prospecting twenty-two inches below the surface, in a place which evidently had never been before disturbed."*

The gathering of Post-Tertiary deposits is of so variable a nature that the deductions of relative age, of any value, except under peculiar circumstances, cannot be drawn from their physical features. Indeed this line of argument has been adopted by the Rev. Peter MacPherson, who, when dealing with the antiquity of aboriginal stone hatchets, selected the Hunter River alluvium for one of his illustrations, showing how easily and quickly it is possible for detrital matter to entomb articles of human workmanship. $\dagger$

We now come to what would at first sight appear to be the most reliable evidence of the geological antiquity of Australian man, but after a careful weighing of the facts, I do not feel justified in attaching to it that amount of importance which the discovery would seem to warrant. I refer to the important statement by the late Gerard Krefft, which he published on at least two occasions, of the occurrence of a human tooth in the Wellington Cave breccia.

I need not dilate on the importance of such a find, if its surroundings can be satisfactorily established. If the tooth, which I am now permitted to exhibit by permission of the Curator of the Australian Museum, was found in the well-known red boneearth or breccia associated with any of the mammals of that period now extinct, it certainly would lend strong colour to the existence of man on this Continent in Post-Tertiary times. To prove this the evidence must be conclusive, not partial; and I regret to say there is just a sufficient want of corroborative evidence, Mr. Krefft's statement notwithstanding, to neutralise the importance of the discovery.

The facts of the case, such as they are, are as follows:-The late Curator of the Australian Museum, in giving a list of the

* “Daily Life and Origin of the Tasmanians," 1870, p. 215.

+ Journ. R. Soc. N. S. Wales for 1885 [1886], xix. p. 117. 
Wellington Cave fossils in the "Guide to the Australian Fossil Remains exhibited by the Trustees of the Australian Museum, \&c.,"* mentions " the fractured crown of a molar tooth, probably a human molar." The second notice occurs in a paper, "Further Discovery of Remains of a Great Extinct Wingless Bird in Australia," wherein he says- "I have found the fractured crown of a human molar in the same matrix as Diprotodon and Thylacoleo, at Wellington, in this colony." $\dagger$

Thanks to the care manifested by Mr. Henry Barnes, at the Australian Museum, of all the Wellington gatherings, the specimen was forthcoming on enquiring for it. That it is the crown of a human molar is, I think, beyond much doubt; but to guard against mistake I placed the specimen in the hands of Mr. P. R. Pedley, who corroborates Mr. Krefft's determination, and further suggests that it is probably of the upper right series. Minute portions of the red cave earth are still adhering to it, but if the tooth ever existed in a block of the breccia, with bones of the extinct marsupial mentioned by Krefft, it has long been removed from such. We have the testimony of Mr. Barnes that the tooth was found at Wellington in the No. 3, or Mitchell's Breccia Cavern, by Mr. Krefft in person, the former having been present at the time. Un the two most important points, however, Mr. Barnes' memory, after this lapse of time, is defective. Was the tooth actually found in a block of breccia with the remains of Diprotodon and Thylacoleo?, or simply lying loose on the floor of the cave?, Mr. Krefft's expression in relation to these animals having perhaps only been used in a figurative sense. In the answers to these questions lies the solution of the problem. If associated in a block of breccia with Diprotodon and other similar remains, it must be admitted that strong evidence exists of the presence of man at the time Diprotodon and Thylacoleo roamed abroad. On the other hand, if merely a floor specimen, it may have entered the cave in a fortuitous manner, and in such a case 
must be looked upon as very poor evidence. The value of this tooth is not increased by the fact that no other human remains have been found in the Wellington Caves under similar circumstances, so far as the writer is aware, although portions of a human skeleton, said to be that of a gin, were found in No. 2 Cave by Mr. Henry Barnes. I am assured by the latter that these were not fossil, and are probably those referred to by Mr. Krefft in the second edition of his "Australian Vertebrata, Recent and Fossil,"* wherein he says-" Bones of the extremities found in a cave at Wellington, being left and right femur, left and right tibia, left and right humerus, portion of fibula." It is, however, strange that Krefft, in the third edition of the same work, published in $1871, \uparrow$ says nothing about the molar or the gin's bones, merely remarking, "Of man we have but scanty evidence regarding the length of his existence here; in not one instance were weapons or implements obtained with the remains of fossil animals."

It will be seen from this that the later remarks of Mr. Krefft himself do not tend to strengthen the view that the tooth in question is worthy to take its place as evidence of man's existence then, in the same manner that the bones of Diprotodon and Thylacoleo do of these animals.

The molar consists of about two-thirds of the crown broken off from the remainder of the tooth, the under surface exposing the fractured dentine. The entire crown is so much worn down as almost to reach the alveolar border. Regarding the tooth as an upper right molar, the two inner cusps are almost worn away, leaving the sulcus dividing them now, as a ridge. The inner anterior cusp is the portion broken away, the inner posterior

* "Australian Vertebrata (Recent and Fossil) representing all the Genera known up to the present time, With Notes," by Gerard Krefft. Cat. Nat. Industrial Prods. N. S. Wales, Paris Univ. Exhib. 1867, p. 91 (8vo, Sydney, 1867. By Authority.)

† "Australian Vertebrata, Fossil and Recent." Industrial Progress of N. S. Wales, Part 3, 1871 (8vo, Sydney, 1871. By Authority), p. 2. 
being ground quite flat. The outer cusps are worn almost into concavities exposing the dentine, the enamel forming a ring or wall round the inner margin.

The tooth appears to be completely fossilised, for on comparing it with the teeth of the larger marsupials from the Wellington Caves, the mineral condition is without question similar.

To sum up, it may be fairly stated:-(1) That up to the present, as at the time Mr. R. B. Smyth wrote, the existence of man's works in any geological deposit above question, has not been shown to exist. (2) That the molar crown found in the Wellington Breccia Cave appears to be that of a human being, and is to all intents and purposes a fossil. (3) That its position in the cave and association with the other organic remains there entombed is open to doubt. (4) That no other human remains have been found at Wellington under similar conditions.

The mineralised condition of the tooth is, of course, its strongest recommendation; but I do not think that, in a momentous question of this kind, and one on which so much theory can be built up, this should be allowed to outweigh other evidence pointing in a different direction.

The matter can hardly be summed up better than by the very reasonable and often correctly applied Scotch verdict of "Not proven."

In conclusion, I would distinctly wish it to be understood that I have not lost sight of the bearing the relative antiquity of the Tasmanian aborigines has on this subject. The former geological connection of Australia and Tasmania now appears to be a generally accepted fact.* The late Mr. James Bonwick regarded the Tasmanians as an older race than the Australians, although emanating from a common centre, and dispersed over a then existing continent of which our present Australia and Tasmania formed portions. If such be the case, how vast a period of time must have elapsed since then, allowing for the formation of the

* J. Bonwick-“Daily Life and Origin of the Tasmanians,” 1870, p. 259. 
channel we now know as Bass' Straits ; and herein lies one of the strongest proofs of man's early existence on the Island Continent of Australia. Notwithstanding this, however, there remains the undoubted fact that we still lack trustworthy geological information of the approximate date of his first advent in Australia.

Addendum.-I omitted to mention the only other reference known to me, which can have any possible bearing on man's connection with our extinct gigantic fauna. I refer to the discovery which the late Rev. J. E. T.-Woods believed he had made of the scraped and cut bones of an extinct bird termed by him Dromaius australis, and with which he supposed the Aborigines to have been co-existent. (See Mr. Woods' "Report on the Geology of the South-Eastern District of the Colony of South Australia, 1886," p. 7 ; “Nat. History of N. S. Wales-An Essay," 1882, p. 27 ; Proc. Linn Soc. N. S. Wales, 1883, VII. p. 387). As, however, but meagre details are given, no figures, and as I have been unable to satisfactorily trace the bones, this possible evidence cannot at present be traced further.

\section{EXPLANATION OF PLATE.}

Fig. 6. - Human Molar from cave breccia, Wellington; crown view ; $\times 2$. Australian Mus.

Fig. 7. - The same; side view; $\times 2$. 


\section{$2 \mathrm{BHL}$ Biodiversity Heritage Library}

Etheridge, Robert and Melo-Costa, Wanessa de. 1890. "Has man a geological history in Australia." Proceedings of the Linnean Society of New South Wales 5, 259-266. https://doi.org/10.5962/bhl.part.18635.

View This Item Online: https://www.biodiversitylibrary.org/item/22899

DOI: https://doi.org/10.5962/bhl.part.18635

Permalink: https://www.biodiversitylibrary.org/partpdf/18635

\section{Holding Institution}

MBLWHOI Library

\section{Sponsored by}

MBLWHOI Library

\section{Copyright \& Reuse}

Copyright Status: NOT_IN_COPYRIGHT

This document was created from content at the Biodiversity Heritage Library, the world's largest open access digital library for biodiversity literature and archives. Visit BHL at https://www.biodiversitylibrary.org. 